\title{
International Exchange of Information in the Field of Direct Taxation
}

\author{
Enshrinement of the concept of exchange of information in conventions for the avoidance of \\ double taxation concluded by the Czech Republic
}

\author{
Karel Brychta \\ Faculty of Business and Management \\ Brno University of Technology \\ Brno, the Czech Republic \\ brychta@fbm.vutbr.cz
}

\author{
Pavel Svirák \\ Faculty of Business and Management \\ Brno University of Technology \\ Brno, the Czech Republic \\ svirak@fbm.vutbr.cz
}

\begin{abstract}
In connection with continually widening public budget deficits and related attempts of States to remove (or at least to eliminate) unfair tax practices, issues regarding the exchange of information, which is necessary for the proper performance of provisions of conventions for the avoidance of double taxation and/or national laws, have become topical. The purpose of this paper which includes starting points for subsequent analyses is to describe and assess the existing situation in the area of enshrinement of the concept of exchange of information in current conventions for avoidance of double taxation concluded by the Czech Republic according to the state valid on 1 January 2013. Having regard to this objective defined, the authors ignore other aspects such as the existence of memoranda of mutual cooperation concerning the exchange of information, existence of tax information exchange agreements concluded by the Czech Republic and Euroepan Union law in the given area and their contents. They briefly refer to these and other aspects in the chapter called "Discussion" where they point to other research possibilities in this area.
\end{abstract}

Keywords-conventions for the avoidance of double taxation, Czech Republic, exchange of information, OECD

\section{INTRODUCTION}

Owens [27] put it very eloquently when he said that the world today was a very small place. In connection with globalization and its accompanying effects, States do not and cannot operate separately in tax matters either [59], [60]. On one hand, they compete with each other in their attempts to gain tax bases, however, on the other hand, they are forced to cooperate. The level of cooperation is obviously different and it can reach (depending on a number of factors) various levels of intensity - from coordination to harmonization [12], [29]. Nevertheless, competition in the given area, according to the authors' opinion, shows similar general attributes which are typical for corporate sectors (for more details regarding the competition attributes and competitiveness in general terms and corporate sectors - see [21]; for a comparison with the competition and competitiveness assessment for the area of taxes see e. g. [18], [24], [39]).

This paper represents a partial output of specific university research project "Research of internal and external factors influencing a firm value, of the Internal Grant Agency at the Brno University of Technology (registration number FP-S-13-2064).
In the context of the utility function by Wilson [24] and in connection with the research problem solved (identifying the standard for the exchange of information enshrined in all conventions for avoidance of double taxation concluded by the Czech Republic), the question arises as to whether the absence of provision (exchange) of information, or lower standard for the provision of information, about a taxpayer and his or her income from the State of source to other States might be an element increasing the taxpayer's utility. In fact, it is clear that a lack of the provision of information can result in an overall reduction in the effective tax rate from global income of taxpayers which clearly indicates a positive answer to the question asked. The fact that it is a human nature to put first individual interests first [6] play a certain role here. Proof of this can be found in the existence and grounds for using of so called tax heavens on the part of taxpayers and large amounts of funds allocated there [28].

However, the issue cannot be viewed only from the taxpayer's perspective. This is because tax collections are crucial resource for financing of public goods without the provision of which the social contract platform based on the ideas of philosophers such as Rousseau, Hobbes or Lock would not be accepted - the State would not properly perform its functions and could not perform its functions on a long-term basis. For obvious reasons, States and international organizations must interfere to prevent the development of unfair and undesirable practices undermining tax collections in such a difficult situation in which a number of States are (see [20]). Thus, there is a challenge to make finance and banking legible at the global scale, moving from idiosyncratic and particularistic national arrangements towards a world-wide uniform bureaucratic grid [22].

In this respect, the Organization for Economic Cooperation and Development (hereinafter referred to as "OECD") plays one of key roles on the international stage. OECD in its notoriously known document Harmful Tax Competition. An Emerging Global Issue noted that the lack of effective exchange of information was associated with harmful tax competition (it is understood as a feature of tax heavens and harmful preferential tax regimes) [43]. However, the OECD 
actions do not lie only in declaratory statements but also in the creation and implementation of required standards (see [44], [45], [46], [47], [50]). The growing intensity of the OECD activities in the area of information exchange can be seen especially in the last two decades [57] which is given mainly in connection with signs of globalization and a precarious state of public finances of a large number of States. Thus, one can consider logical that the participation and involvement of the States in such activities has been growing [51]. Of course, there has been also a "friendly pressure" from the OECD and those States which already participate.

As for the exchange of information, a shift to stricter rules can be seen in the model convention of the OECD. This fact is relevant also in terms of the research task solved since it is a model used by the Czech Republic when negotiating conventions for the avoidance of double taxation (hereinafter referred to as "CADT").

\section{OBJECTIVE AND METHODOLOGY}

The purpose of this paper is to compare the wording of Articles governing the exchange of information included in all current CADTs concluded by the Czech Republic according to the state valid on 1 January 2013 and to identify the standard for the exchange of information enshrined in them. As to the list of relevant CADTs, the authors relied on the official overview of CADTs which was published in the annual notice by the Ministry of Finance of the Czech Republic [53].

Content analysis of the texts of selected provisions of the CADTs in question was used as a basic method for data collection. The aspects observed on which the subsequent classification of CADTs was based were:

a) general provision defining the scope of information to which the relevant Article enshrining the exchange of information applies;

b) personal and material scope of the Article within the meaning whether the personal and material scope is limited by the Article 1 and Article 2 of the relevant CADT;

c) situations which exclude the obligation of the State concerned to provide the information given;

\section{d) existence of other specific provisions.}

To determine the level of association between categories followed, the Cramer's V coeficient based on the test statistic of $\chi^{2}$ (for coefficient $\alpha=0.05$ ) was used (formulas used from [25]). Drafted contingency tables created from the input data set elaborated by the authors were the background for the calculations made.

The structure of the paper is as follows. After the general introduction specifying the framework legislative enshrinement regarding the exchange of information in the Czech Republic, the authors of this paper present their results from the comparison of the texts of the Articles governing the exchange of information. They use tables for the sake of clarity. In the following chapter called Discussion, the authors assess the results achieved while referring to other related issues that should be assessed in connection with the exchange of information and on which they intend to focus within possible subsequent analyses.

Unless noted otherwise, the legislation included in the paper corresponds to the state valid on 1 January 2013. For gaining the text of the CADTs, the ASPI (Automatized System of Legal Information) [11] was used.

\section{RESULTS}

\section{A. Framework legislative enshrinement of mutual exchange} of information in the Czech Republic

The concept of mutual exchange of information in the tax area is enshrined in international law, European Union law (hereinafter referred to as "EU law") and understandably in national (domestic) legislation. For the sake of clarity, the fundamental legislative framework in the Czech Republic is specified in Table I. It is worth mentioning that the list is not exhaustive and with regard to the paper focus, only framework legislation in the area of direct taxes is mentioned (income taxes and property taxes).

\section{TABLE I. FUNDAMENTAL LEGAL REGULATION IN THE CZECH REPUBLIC}

\begin{tabular}{|l|l|}
\hline $\begin{array}{c}\text { Category of } \\
\text { law }\end{array}$ & \multicolumn{1}{|c|}{ Legal regulations (category of legal regulations) } \\
\hline \multirow{5}{*}{ International } & $\begin{array}{l}\text { Conventions for the Avoidance of Double Taxation }+ \\
\text { Protocols to these Conventions }{ }^{\mathrm{a}} \\
\text { Memoranda on cooperation in the area of automatic } \\
\text { exchange of information for tax purposes } \\
\text { Memoranda on understanding in the area of } \\
\text { automatic exchange of tax information for tax } \\
\text { pursposes }\end{array}$ \\
\hline EU law & $\begin{array}{l}\text { Council Directive 2011/16/EU on administrative } \\
\text { cooperation in the field of taxation and repealing } \\
\text { Directive 77/799/EEC of 15 February 2011 } \\
\text { Council Directive 2003/48/EC on taxation of savings } \\
\text { income in the form of interest payments }\end{array}$ \\
\hline Domestic & $\begin{array}{l}\text { Act No. 164/2013 Coll., on international cooperation } \\
\text { within tax administration and on changes of other related } \\
\text { acts }\end{array}$ \\
\hline
\end{tabular}

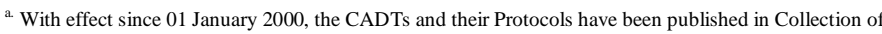
International Treaties (hereinafter referred to as "Coll. of IT"); previous (older) CADTs have been published in Collection of Laws (hereinafter referred to as "Coll.")

b. With effect since 21 June 2013.

\section{B. International law}

In the area of international law, CADTs, which include a separate article, usually with an appropriate title "exchange of information", are a crucial source of law for the given area (i.e. international exchange of tax information).

According to the state valid on 01 January 2013, the Czech Republic had concluded 80 valid CADTs. It worths mentioning that the number of CADTs concluded by the Czech Republic has been continually increasing which can be undoubtedly assessed as a positive trend (a growing number of CADTs can be, in certain phases, attributed also to the formation of new States associated especially with the fall of the former state formations such as the Soviet Union and Yugoslavia).

The visulation of the years of publication of CADTs (or its amended versions) can be seen in Fig. 1. 


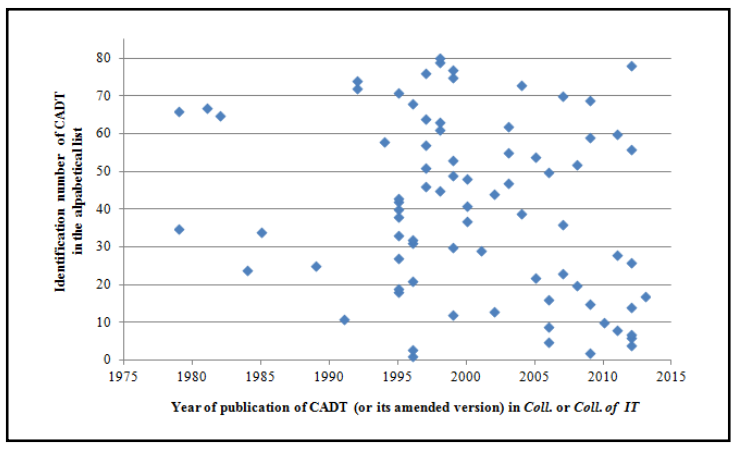

Fig. 1. Years of publication of particular CADTs - an overview.

The Czech Republic has been recently very active also in relation to the States which are or have been called "tax heavens". Nowadays, the Czech Republic has tax information exchange agreements (hereinafter referred to as "TIEA") concluded e.g. with the British Virgin Islands (published under No. 6/2013 Coll. of IT), Jerssey (published under No. 5/2012 Coll. of IT), Bermuda (published under No. 48/2012 Coll. of IT), the Isle of Man (published under No. 3/2013 Coll. of IT), Guernsey (published under No. 2/2013 Coll. of IT) and the Republic of San Marino (published under No. 4/2013 Coll. of IT) [11]. As can be seen from the publication dates in the Collection of International Treaties, the TIEAs are relatively new in the area of international income taxation. It is a new instrument of international cooperation through which the information exchange system is being spread outside the European Union (hereinafter referred to as "EU") and OECD members [58]. However, the growing number of concluded CADTs and agreements on the exchange of information does not mean, in itself, an overall improvement of the situation in the given area.

\section{Legislation regarding the exchange of information included in the relevant articles of CADTs}

As mentioned above, the authors deal with a relatively narrow segment of the issues given - legislation included in the Article enshrining the concept of exchange of information - in their paper. The authors focus their attention on:

a) general provision (clause) specifying the scope of the information exchanged,

b) personal and material scope of information exchange,

c) situations which exclude the obligation of the State concerned to provide the information given,

\section{d) existence of other specific provisions.}

Within this paper, provisions regarding the treatment of information provided (for more details regarding this issue see [49]), which are also enshrined in the relevant Articles of CADT, have not been compared.

The first aspect of observation was to identify a basic clause specifying the scope of exchange of information. Within the CADTs concluded by the Czech Republic, the authors have identified five various clauses which are influenced both by the model (models) used when concluding the CADT and by the time model version and understandably by the contractual freedom of contracting parties (States) when concluding the CADT. The findings are summarized in Table II (the table contains not only the numbers but also an exhaustive list including specification of contracting States and publication dates of the CADTs and their eventual Protocols amending them in the official collection (Collection of Laws or Collection of International Treaties).

TABLE II. GENERAL CLAUSE FOR EXCHANGE OF INFORMATION

\begin{tabular}{|c|c|c|}
\hline Wording of General Clause & Contracting State and year of publishing the CADT in an official Collection & $\begin{array}{l}\text { Number } \\
\text { of CADTs }\end{array}$ \\
\hline $\begin{array}{l}\text { information as is necessary for carrying out the } \\
\text { provisions of the Convention (information as is } \\
\text { necessary for the application of the provisions of the } \\
\text { Convention }^{c} \text { ) or of the domestic laws }\end{array}$ & $\begin{array}{l}\text { Albania (1996); Australia (1996); Azerbaijan (2006); Belgium (2006); Bosnia and } \\
\text { Herzegovina (2010); Bulgaria (1999); Egypt (1995); Estonia (1995); Ethiopia (2008); } \\
\text { Finland (1996); France (2005); Greece (1989); Georgia (2007); Hungary (1995); } \\
\text { Iceland (2001); Indonesia (1996); Ireland (1996); Israel (1995); Japan (1979); } \\
\text { Kazakhstan (2000); Korea (1995); Kuwait (2004); Lebanon (2000); Lithuania (1995); } \\
\text { Latvia (1995); Luxembourg (1995); Macedonia (2002); Malta (1997); Morocco } \\
\text { (2006); Mexico (2003); Moldova (2000); Nigeria (1991; amended in 1999); Portugal } \\
\text { (1997); Romania (1994); United Arab Emirates (1997); Singapore (1998); Slovakia } \\
\text { (2003); Slovenia (1998); South Africa (1997; explicitly stated requirement for a } \\
\text { consultation for formation of suitable conditions and procedures); Spain (1982); } \\
\text { Sweden (1981); Syria (2009); Tajikistan (2007); Thailand (1995); Tunisia (1992); } \\
\text { Turkey (2004); United States of America (1994, amended in 1999); United Kingdom } \\
\text { of Great Britain (1992); Vietnam (1998) }\end{array}$ & 49 \\
\hline $\begin{array}{l}\text { information as is necessary for carrying out the } \\
\text { provisions of the Convention or domestic laws with } \\
\text { explicitly stated emphasis on protection against tax } \\
\text { avoidance or evasion in relation to taxes in question }\end{array}$ & $\begin{array}{l}\text { Canada (2002); Democratic People's Republic of Korea (2006); India (1999; } \\
\text { information including documents); Italy (1985); Jordan (2007); Malaysia (1998); } \\
\text { Mongolia (1999); Philippines (2003); Ukraine (1999); Venezuela (1998, explicitly } \\
\text { stated requirement as to the conditions, methods and techniques) }\end{array}$ & 10 \\
\hline $\begin{array}{l}\text { information as is necessary for the application of the } \\
\text { provisions of the Convention }\end{array}$ & Brazil (1991); Germany (1984); Switzerland (1996) & 3 \\
\hline $\begin{array}{l}\text { information as is inecessary for carrying out the } \\
\text { Convention, especially for the purpose of prevention } \\
\text { from frauds, and as is necessary for carrying out legal } \\
\text { enactment against tax evasion (Netherlands) } \\
\text { information as is necessary for the provisions of the }\end{array}$ & $\begin{array}{l}\text { Netherlands (1974, amended in } 1997 \text { - explicitly excluded duty to provide information } \\
\text { acquired from banks or institutions of the same kind); Sri Lanka (1979) }\end{array}$ & 2 \\
\hline
\end{tabular}




\begin{tabular}{|l|l|l|}
\hline \multicolumn{1}{|c|}{ Wording of General Clause } & \multicolumn{1}{|c|}{$\begin{array}{c}\text { Number } \\
\text { of CADTs }\end{array}$} \\
\hline $\begin{array}{l}\text { Convention or for the purpose of prevention against } \\
\text { tax frauds or for the purpose of carrying out the } \\
\text { measures against tax evasion (Sri Lanka) }\end{array}$ & \\
\hline $\begin{array}{l}\text { information as is foreseeably relevant for carrying } \\
\text { out the provisions of this Convention or to the } \\
\text { administration or enforcement of the domestic laws }\end{array}$ & $\begin{array}{l}\text { Armenia (2009); Austria (2007, amended in 2012); Bahrain (2012); Barbados (2012); } \\
\text { Cyprus (2009); Denmark (2013); Hongkong-China (2012); New Zealand (2008); } \\
\text { Norway (2005); Poland (2012); Russia (1997, amended in 2009); Serbia and } \\
\text { Montenegro (2005; amended in 2011); Uzbekistan (2001, amended in 2012); }\end{array}$ \\
\hline $\mathrm{x}$ & \begin{tabular}{l} 
In Total \\
\hline
\end{tabular} \\
\hline
\end{tabular}

c. There are two basic different wordings - some CADTs use a diction "carrying out the provisions of the Convention", the other use term "application of the provisions of the Convention". d. The wordings in CADT with Netherlands and Sri Lanka are very specific ones; that is why they are given in a separate category.

In relation to the first aspect of observation (identifying a basic clause specifying the scope of exchange of information), it can be concluded that the most common diction of the general clause for exchange of information sounds as information as is necessary for carrying out the provisions of the Convention or of the domestic laws.

In case of newer CADTs, there is a shift to the specification of the extent of exchange of information as is foreseeably relevant for carrying out the provisions of the Convention or to the administration or enforcement of the domestic laws. The last mentioned reflects the new wording of the Article given in the OECD Model Convention the purpose of which is to widen the scope of exchange of information given [46]. A significant number of CADTs explicitly accent the exchange of information in order to eliminate tax frauds or evasion.

Another step consisted in comparing the personal scope (persons covered by the convention) and material scope (taxes covered by the convention) of the Article enshrining the exchange of information in CADTs. Personal scope limitation means limiting the impact only to the subjects mentioned in Article 1 of the CADT (namely persons who are residents of one or both of the contracting States). In case of eliminating this limitation, the exchange of information shall be applied to all other taxpayers (i.e. non-residents). Material scope limitation means that the CADT has an impact only on the taxes specified in Article 2 of the relevant CADT (income taxes and in case of some CADTs also property taxes). CADTs can potentially lay down four of the under-mentioned variations:

a) application of the Article governing the exchange of information is not limited by Article 1 or Article 2 of the relevant CADT (it is related both to information about tax residents and about non-residents and the exchange of information can also be related to all taxes imposed by the State given - not only to those specified in Article 2 of the relevant $C A D T)$ - hereinafter referred as variant $A$;

b) application of the Article governing the exchange of information is not limited in the personal scope of Article 1 but it is related only to the taxes specified in Article 2 of the relevant $C A D T)$ - hereinafter referred as variant $B$;

c) application of the Article governing the exchange of information is limited both by Article 1 and by Article 2 of the relevant $C A D T$ - hereinafter referred as variant $C$; d) application of the Article governing the exchange of information is limited in the personal scope only; i.e. it is related only to tax residents of one or both of contracting States and the exchange of information can be provided in relation to all taxes (the authors of this paper have not encountered this variation in connection with the CADTs concluded by the Czech Republic, and therefore, it is mentioned as the last variant (for the sake of completeness) hereinafter referred to as variant $D$.

For the sake of clarity, the findings achieved are summarized in Table III.

\section{TABLE III. PERSONAL AND MATERIAL SCOPE OF CONCLUdED CADTS}

\begin{tabular}{|c|c|}
\hline Variant & Number of CADTs \\
\hline A & 27 \\
\hline B & $37^{\mathfrak{e}}$ \\
\hline C & 16 \\
\hline D & 0 \\
\hline In Total & 80 \\
\hline
\end{tabular}

e. The CADT with Sri Lanka does not specify the persons covered by the Convention at all. Thus, authors of the paper have come to the conclusion that the personal scope is not limited (in case there had been an intention to limit the personal scope, this intention would have been reflected in the text of the CADT)

As for the comparison of the material and personal scope of the Articles laying down the exchange of information, it was found out that the limitation of the material scope of CADT to taxes which are its subject and with the personal scope goes beyond the subjects mentioned in Article 1 is a prevailing conception (variant B). This fact is very significant for a number of States which apply the conception of so called unlimited tax liability to tax residents (see [36] for more details regarding this issue) - i.e. a tax resident admits income from sources in the territory of the State of his or her residence as well as from other States for taxation in the State of his or her tax residence.

However, in case of the EU Member States, which fall within this CADT category (material scope limitation, personal scope without limitation - referred to as variant B), a much higher standard in the area of international exchange of tax information is guaranteed by secondary EU law. In connection with this statement it worths mentioning that an overall majority of Member States of EU fall just within this category referred to as variant $B$. 
Another aspect compared was identification of the situation excluding the obligation of the States to provide information. In fact, an overwhelming majority of CADTs (in total 78 out of 80 ) include more or less the same basic definitions and even the way of formulation of the facts when the contracting States are not obligated to provide information. It is specified that the appropriate provisions of the relevant Article laying down the exchange of information shall not be construed so as to impose the obligation:

a) to carry out administrative measures at variance with the laws and administrative practice of that or of the other Contracting State;

b) to supply information which is not obtainable under the laws or in the normal course of the administrative practice of that or of the other Contracting State;

c) to supply information which would disclose any trade, business, industrial, commercial or professional secret or trade process, or information the disclosure of which would be contrary to public policy (ordre public).

The diction (formulation) of the two remaining CADTs (CADT with Sri Lanka and CADT with Switzerland) as to the aspect inquired is quite different in this regard. However, their content agreement can be de facto deduced - at least for the most part.

Within the comparison, the authors also identified other provisions which are included in the minority of concluded and valid CADTs of which the Czech Republic is a contracting party. Some of CADTs explicitly include the provision which guarantees that the requested State shall use its measures to obtain the information requested even though it may not need such information for its own tax purposes. This obligation does not affect the limitations specified above, but it cannot be construed as a permission to refuse the provision of information only for the reason that the domestic (requested) state is not interested in such information. In this respect, the CADTs with USA, Mexico and Canada [11] have its own characteristics in formulation of the relevant texts but the essence of the provisions is the same. In the CADT with USA there is even explicitly stated that the information shall be provided in the form of depositions of witnesses and authenticated copies of unedited original documents (including books, papers, statements, records, accounts, and writings). Furthermore, the authors of the paper found out that majority of these CADTs contain a clause ensuring a certain breakthrough in the area of bank secrecy. According to the diction of this clause, limitations in the provision of information cannot be construed as a permission of a contracting state to decline to supply information solely because:

a) the information is held by a bank, other financial institution, nominee or person acting in an agency or a fiduciary capacity,

b) or because it relates to ownership interests in a person.
The summarization of the findings is stated in Table IV which lists contracting States where an appropriate CADT, where the Czech Republic is a contracting State, includes the provision ensuring the provision of information, even if the requested State may not need such information for its own tax purposes (specified as provision I), and the provision ensuring a certain breakthrough in the area of bank secrecy (specified as provision II).

TABLE IV. SPECIAL PROVISIONS IN CADTS

\begin{tabular}{|c|c|c|c|}
\hline \multirow{2}{*}{$\begin{array}{c}\text { Contracting State and year of } \\
\text { publishing the CADT in an official } \\
\text { Collection }\end{array}$} & \multirow{2}{*}{ Number } & \multicolumn{2}{|c|}{ Provision } \\
\hline & & $I$ & II \\
\hline $\begin{array}{l}\text { Armenia (2009); Austria (2007, } \\
\text { amended in 2012); Bahrain (2012); } \\
\text { Barbados (2012); Belarus (1998, } \\
\text { amended in 2011); China (2011); } \\
\text { Denmark (2013); Hongkong-China } \\
\text { (2012); Croatia (2000, amended in } \\
\text { 2012); Norway (2005); New Zealand } \\
\text { (2008); Poland (2012); Russia (1997, } \\
\text { amended in 2009); Serbia and } \\
\text { Montenegro (2005, amended in 2011); } \\
\text { Uzbekistan (2001, amended in 2012) }\end{array}$ & 15 & yes & yes \\
\hline $\begin{array}{l}\text { Canada (2002); Mexico (2003); United } \\
\text { States of America (1993, amended in } \\
1999)\end{array}$ & 3 & yes & no \\
\hline In Total & 18 & $\mathrm{x}$ & $\mathrm{x}$ \\
\hline
\end{tabular}

Only three of the above-mentioned CADTs do not include the special provision meaning a certain breakthrough in the area of bank secrecy. It concerns the CADTs with the different wording of the provision I.

\section{Associations between investigated categories and some trends}

To determine the level of association between investigated categories, the Cramer's V coefficient which is based on the $\chi^{2}$ test statistic was used; $\alpha$ coefficient was set as $5 \%$. Drafted contingency tables created from the input data set elaborated by the authors were the background for the calculations, the result of which is stated in Table $\mathrm{V}$ below.

TABLE V. CRAMER'S V COEFFICIENTS

\begin{tabular}{|l|c|c|c|}
\hline & $\begin{array}{c}\text { OECD } \\
\text { Membership }\end{array}$ & $\begin{array}{c}\text { General } \\
\text { clause }\end{array}$ & Scope \\
\hline Special clause I & 0.109985 & 0.389919 & 0.402794 \\
\hline Scope & 0.136354 & 0.392428 & $\mathrm{x}$ \\
\hline General clause & 0,106640 & $\mathrm{x}$ & $\mathrm{x}$ \\
\hline
\end{tabular}

As can be seen in Table $\mathrm{V}$, there is a very low association between OECD membership of the contracting State and the content of the article governing the exchange of information. Thus, one can observe there is a very low difference between CADTs concluded with OECD member and non-member States.

Particular clauses, however, show substantially higher level of associations. That is to say, there is a tendency to connect certain types of the clauses governing particular issues 
together. This is obvious also from comparison of the Fig. 2 and Fig. 3.

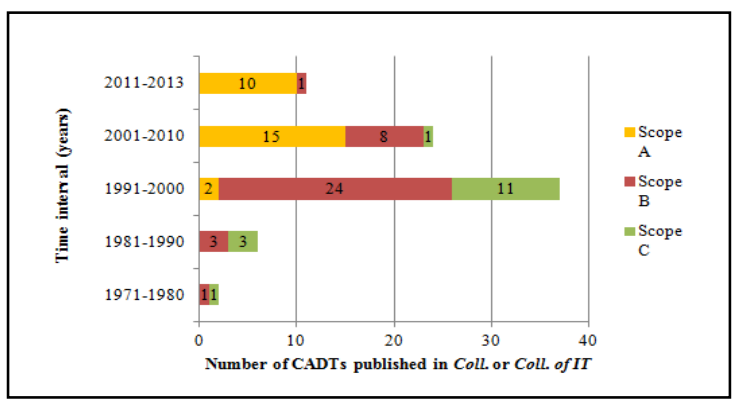

Fig. 2. Number of published CADTs - criterion Scope.

During the analysis it was found out a clear tendency to tightening the rules, which can be demonstrated among others also by the tendency to define the personal and material scope widely (Scope A) and by the tendency to define the general clause very broadly (General clause E).

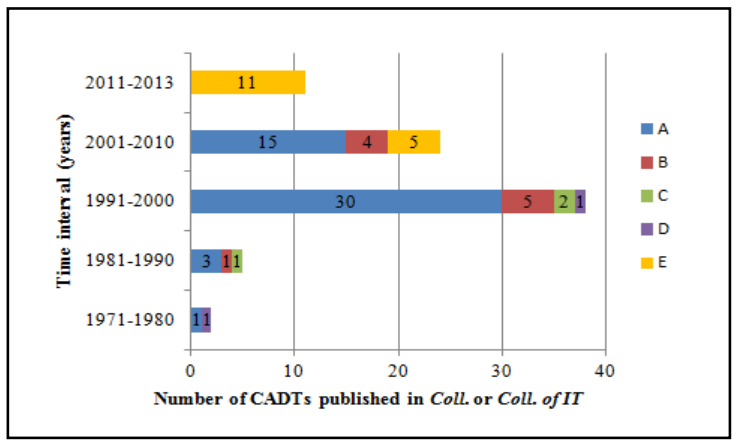

Fig. 3. Years of publication of particular CADTs.

\section{DISCUSSION}

The era of considerable significance of information exchange and transparency of tax systems started at the beginning of this millennium [34], [57]. At the same time it can be concluded that international exchange of information became a central issue in international tax policy and was considerable boosted by the financial crises in 2009 [42]. One of the reasons is the fact that the international exchange of tax information is perceived as an instrument contributing to the elimination of tax evasion and as a method of acquiring other funds for public budgets [7], [28]. Losses for public finances resulting from tax evasion and avoidance with the shadow economy in EU are estimated to be around one fifth GDP on average ( $€ 2$ trillion) [13]. However, it is a global problem, not problem in EU only (see e. g. [31]).

On the global forum the OECD can be considered a key player. The OECD acts, as already mentioned above, as a creator of standards for international exchange of tax information. These standards are not reflected only in the OECD model convention [45], [46] but also in a number of other documents enshrining rules and principles for the exchange of information (see [47], [49]). It should also be noted that thanks to the impact of the OECD, a progress has been made in this field. Many States has been involved in OECD activities and some achievements have been accomplished [37], [48]; however, there are still many problems affecting the real functioning of the effective exchange of information [52]. That is to say, some measures and actions seem to have failed to reach the results expected in some respect (at least at the beginning of their factual enforcing) - these are especially the OECD actions in relation to TIEAs [2], [3], [5], [17], [26], [28], [38], [55]. In this respect, existence of secrecy jurisdiction has been perceived to be a huge problem (e. g. [23]). Speaking of the area of international cooperation in tax affairs it is also pointed to the fact that the fundamental problem with cooperation in the modern international tax regime is just that it builds on the tax treaty model, thus effectively excluding countries which have not enetered into tax treaties [1].

In connection with the international exchange of information, it should be underlined that enshrinement of the concept of "exchange of information" and cooperation between States in the given area is not, in itself, a guarantee for the utility of the provision given - neither is a growing number of CADTs and/or TIEAs. It is essential to ensure that the exchange of information is effective which is achieved when the information requested is provided in a timely manner and when there is a legal mechanism enabling to obtain and exchange the information requested [57]. Despite positive trends in the area given, the current situation is not assessed as satisfactory, very often stressing a need of a multilateral system [19], [56]. In this regard, e.g. the United States has accepted its own measures with a reference to the insufficient effectiveness of previous measures. This mainly involved a U.S. Foreign Accounts Tax Compliance Act (hereinafter reffered to as "FATCA") which has led and leads to enforcing the measures at the international level as well as to determining Union law [16], [17], [32]. It should provoke some improvements in current EU regulations which are considered not tight enough in some aspects (e. g. [54]). The fact is that one cannot probably expect this effect in case of measures accepted by individual small states; for their enforcement, the initiator must be a strong subject on the international stage.

In case of the Czech Republic, adoption of any domestic regulation (or measure) which would have a significant domestic overlap cannot be expected. Though, the Czech Republic recently accepted (with effect from 1 January 2013) the measure which disadvantages taxpayers (Czech nonresidents) from non-contracting States with incomes from the sources in the territory of the Czech Republic. For the purposes of the previous statement, the non-contracting States are the States with which the Czech Republic has no CADT or TIEA concluded. In case of payment of the income given to these non-residents of the Czech Republic, the payer is obliged to deduct a tax in the amount of $35 \%$ from gross income [4] (compare with the measures accepted in FATCA [15], [17]). Of course, this rule containted in Czech Act on Income Taxes does not impact on EU or European Economic Area tax residents [4].

\section{A. Selected results of research made}

Based on the comparison made, the Czech Republic seems to proceed to renegotiation of some of old CADTs and to their replacement with the new ones which include a higher standard 
in the area of exchange of information. Newer CADTs include a more general and wider provision specifying the scope of information provided.

In case of newer CADTs (CADTs which were published in the Collection of International Treaties after 2005) or CADTs, which were amended by the Protocol, it can be concluded that the personal and material scope of these CADTs goes beyond Article 1 and Article 2 of appropriate CADTs. In case of some of newer CADTs, the elimination of the possibility to decline the provision of information with a reference to bank secrecy is also typical. It can therefore be concluded that the rules for the provision of information are becoming stricter and stricter.

Regarding the specification of conditions (facts) under which there is no obligation of an appropriate State to provide information, one can observe a consensus in the text of the CADTs concluded. However, the authors think that just the provision referring to the domestic administrative practice, law, information obtainable under the laws or in the normal course of the administrative practice or information the disclosure of which would be contrary to public policy (ordre public) raises a range of issues and potential threats to factual and effective exchange of information. Disparities between the laws and administrative practice as well as e.g. a different perception of the category of public policy can lead to diametrical differences in the conditions eliminating the provision of requested information.

Besides, only 18 out of the total of 80 CADTs include the explicit provision laying down the obligation of the requested State to supply such information even though it may not need such information for its own tax purposes (however, limitations for the provision of information shall remain preserved). 15 out of these CADTs include the provision (clause) breaking the principle of bank secrecy which is generally perceived as a huge problem in the area of international income taxation [25] and there is a tendency to eliminate it, the question is whether the measures taken are effective (to this issue see [25], [30], [38], [40], [46]). In fact, the higher standard specified above concerns only renegotiated CADTs or older CADTs amended by Protocol (a Protocol of the CADT forms an immanent part of the CADT itself [41]).

\section{B. Limits of achieved results and a space for further research in the given area}

The paper deals with a relatively narrow segment of issues and moreover, from the perspective of one State - the Czech Republic. However, focusing on the Czech Republic can be interesting for several reasons:

\section{a) it is a small open economy, \\ b) it is a Member State of EU.}

Thus, it can be perceived as a representative of the given groups, and findings related to this state can be assessed against the background of general trends or in comparison with other States.

If we focus on the issue of international exchange of information, namely again from the perspective of the Czech
Republic, a number of research questions shall arise. Based on the authors' opinions, they can be divided into several basic areas.

The first area is focused not only on describing and assessing the current domestic legislation and its compliance with EU law but also on the planned future state and its adequacy. As for the international exchange of tax information in the area of direct taxes, the EU law is given by Directives (see [8], [9], [33]), which were incorporated by the Czech Republic in its acts. For the year 2013 new legislation which should better reflect the current situation and requirements imposed on the effective international tax administration was adopted (see [10]). However, the enshrinement of the appropriate legislation does not mean, in itself, an improvement. The question regarding the factual situation and use of the possibility to obtain appropriate information remains open. With hindsight, on the basis of statistical data, it would be also suitable to evaluate the application of the concept of exchange of information on the part of the Czech Republic and other States for all categories of exchange of information (there are three types: exchange of information on request, spontaneous and automatic; the last mentioned category is considered to be a crucial one [13], [14], [15], [37], [47]). At the same time it should be stressed that finding ways to utilize the mass of information received under automatic sharing has been a significant technical challenge [35]. For more information on individual information categories see e.g. [44].

Identifying the standard for treating the information provided could be also a subject of further interest and research. However, after making a quick comparison, the agreement of CADTs is again obvious - then, there is still the question of identification and comparison of appropriate domestic regulations. In this regard, the authors are afraid that in a number of States, it will be difficult or impossible to trace this information; however, this information can be obtained for the OECD member countries [47].

In connection with CADTs, it would be also suitable to describe, compare and assess the rules included in appropriate memoranda (while considering the EU law in case of EU Member States).

The separate chapter, which may be of special concern, could be devoted to the TIEAs and their factual use within the Czech tax administration. Since these agreements are relatively new instruments, it will take some time in order this research task could be solved.

\section{CONCLUSION}

The purpose of this paper was to identify the standard for the exchange of information laid down in all CADTs where the Czech Republic is a contracting State (according to the state valid on 1 January 2013). Within the comparison made, the authors observed selected aspects, specifically:

a) general provision specifying the scope of the information provided,

b) personal and material scope of the Article laying down the exchange of information, 
c) comparison of situations (facts) which eliminate the obligation of an appropriate State to provide the information given and

\section{d) existence of other specific provisions.}

In the introductory part of their paper, the authors described the framework legislative enshrinement for the exchange of information in the Czech legal order. Then, the results of the comparison of selected provisions of all 80 CADTs were presented. The results gained from the comparison made indicate that amended CADTs or renegotiated CADTs lay down a higher standard for the exchange of information compared to the older CADTs. It is clear that the Czech Republic also comes to tightening the rules and to accepting "protectionist" measures at the international level which should ensure the elimination of unfair tax practices (tax evasion). Though, it must be critically pointed out that a large number of CADTs have their material scope limited only to the taxes which are subject to an appropriate CADT. This deficit is partially remediated by the fact that a number of these CADTs are those concluded by Member States of EU where a higher standard for the area of international exchange of tax information remediates this shortage at least partially.

\section{REFERENCES}

[1] A. H. Rosenzweig, "Thinking outside the (tax) treaty," Wisconsin Law Review, vol. 2012, pp. 717-786, Issue 3, 2012.

[2] A. Sawyer (2011). "The OECD' S TAX INFORMATION EXCHANGE AGREEMENTS. AN EXAMPLE OF (IN)EFFECTIVE GLOBAL GOVERNANCE?," Journal of Applied Law and Policy. [Online]. pp. 41-54. Available: http://business.curtin.edu.au/local/docs/JALAP_2011_combined.pdf. [June 15, 2013]

[3] A. Sawyer, "Peer Review of Tax Information Exchange Agreements: Is it More Than Just About the Numbers?," Australian Tax Forum, vol. 26, pp. 397-427, July 2011.

[4] Act No. 586/1992 Coll., on Income Taxes, as amended (Article 36 paragraph (1) letter c))

[5] Author not specified (2013, February 16). "Tax transparency. Automatic response. The Way to make exchange of tax information work.", The $\begin{array}{lll}\text { Economist. } & \text { [Online]. Available: }\end{array}$ http://www.economist.com/news/special-report/21571561-way-makeexchange-tax-information-work-automatic-response. [June 17, 2013].

[6] C. Carmen, "The Possible Causes of Tax Evasion in Romania," in Selected Topics in Economy \& Management Transformation. Volume I. Proceedings of the $5^{\text {th }}$ WSEAS International Conference on Economy and Management Transformation, Romania, 2010. pp. 412-416.

[7] Committee on Economic and Monetary Affairs (2013). Report of 03 May 2013 on Fights against Tax Fraud, Tax Evasion and Tax Havens (2013/2060(INI) [Online]. Available: http://www.europarl.europa.eu/sides/getDoc.do?pubRef=//EP//TEXT+REPORT+A7-2013-0162+0+DOC+XML+V0//EN. [July 09, 2013].

[8] Council Directive 2003/48/EC on taxation of savings income in the form of interest payments. [Online]. Available: http://eurlex.europa.eu/LexUriServ/LexUriServ.do?uri=CELEX:32003L0048:EN :NOT. [May 25, 2013].

[9] Council Directive 2011/16/EU on administrative cooperation in the field of taxation and repealing Directive 77/799/EEC of 15 February 2011. [Online]. Available: http://eurlex.europa.eu/LexUriServ/LexUriServ.do?uri=OJ:L:2011:064:0001:01: EN:HTML. [May 25, 2013].

[10] Czech Act No. 164/2013 Coll., on international cooperation within tax administration and on changes of other related acts.
[11] Czech Collection of Laws and Czech Collection of Tax Treaties in ASPI [Automatizovaný Systém právních informací]. Wolters Kluwer, a. s. (C) 2013. [Automatized (Computerized) System of Legal Information - in Czech]

[12] D. Nerudová, Harmonizace daňových systémů zemi Evropské unie, 3rd ed., Praha: Wolters Kluwer, 2011. pp. 15-19. [Harmonization of Tax Systems of EU Countries - a book in Czech]

[13] European Commission (2012, 27 June). MEMO. Tackling tax fraud and evasion in the EU - frequently asked questions. Available: http://europa.eu/rapid/press-release_MEMO-12-492_en.htm. [December 20, 2012].

[14] European Commission (2012, December 06). COMMUNICATION FROM THE COMMISSION TO THE EUROPEAN PARLIAMENT AND THE COUNCIL. An Action Plan to strengthen the fight against tax fraud and tax evasion. Available: http://ec.europa.eu/taxation_customs/resources/documents/taxation/tax_f raud_evasion/com_2012_722_en.pdf. [February 02, 2013].

[15] European Commission (2013, June 12). Automatic exchange of information: frequently asked questions. [Online]. Available: http://europa.eu/rapid/press-release_MEMO-13-533_en.htm. [July 05, 2013].

[16] European Commission (2013, June 12). Proposal for a COUNCIL DIRECTIVE amending Directive 2011/16/EU as regards mandatory automatic exchange of information in the field of taxation. [Online]. Available:

http://ec.europa.eu/taxation_customs/resources/documents/taxation/tax_ cooperation/mutual_assistance/direct_tax_directive/com_2013_348_en.p df [July 12, 2013]

[17] F. Campano and F. Zipfel. (2013, January). "FATCA \& Intergovernmental Agreements. Automatic exchange of information on taxes on the rise." Deutsche Bank Research. [Online]. Available: http://dbresearch.com. [June 05, 2013].

[18] G. R. Zodrow, "Tax Competiton and Tax Cooperation in the European Union," International Tax and Public Finance, vol. 10, pp. 651-671, November 2003.

[19] I. Grinberg, "The Battle Over Taxing Offshore Accounts," UCLA LAW REVIEW, vol. 60, pp. 304-383, December 2012.

[20] International Monetary Fund (2013). World Economic and Financial Surveys. Fiscal Monitor. Fiscal Adjustment in an Uncertain World. [Online]. Available: http://www.imf.org/external/pubs/ft/fm/2013/01/pdf/fm1301.pdf. [July 02, 2013].

[21] J. A. Jirásek, Konkurenčnost: vítězství a poŕásky na koblišti trhu, 1st ed., Praha: Professional Publishing, 2001. [Competitiveness: Victories and Defeats in the Market Arena - a book in Czech]

[22] J. C. Sharman, "Seeing Like the OECD on Tax,"New Policital Economy, vol. 17, pp. 17-33, Issue 1, 2012. DOI: 10.1080/13563467.2011.569022

[23] J. Christensen, "The hidden trillions: Secrecy, corruption, and the offshore interface," Crime, Law and Social Change, vol. 57, pp. 325343, April 2012.

[24] J. D. Wilson, “Theories of Tax Competition," National Tax Journal, vol. 52, pp. 269-304, June 1999.

[25] J. Hendl, Přehled statistických metod, $4^{\text {th }}$ ed., Praha: Portál, 2012. pp. 321-323. [An Overview of Statistical Methods - a book in Czech].

[26] J. McLaren and J. Passant (2010), "Tax havens: do they have a future providing banking and financial services?," Canberra Law Review. [Online]. vol. 9, No. 1, pp. 1-23. Available: http://www.austlii.edu.au/au/journals/CanLawRw/2010/3.html. [June 17, 2013].

[27] J. Owens, "Globalisation: The implications for tax policies," Fiscal Studies, vol. 14, pp. 21-44, August 1993.

[28] J. S. Henry (2012). THE PRICE OF OFFSHORE REVISITED. NEW ESTIMATS FOR "MISSING" GLOBAL PRIVATE WEALTH, INCOME, INEQUALITY, AND LOST TAXES. [Online]. Available: http://www.taxjustice.net/cms/upload/pdf/Price_of_Offshore_Revisited_ 120722.pdf. [July 01, 2013].

[29] J. Široký, Daně v Evropské unii, 5th ed., Praha: Linde, 2012. pp. 28-32. [Taxes in European Union - a book in Czech]. 
[30] K. Neslund (2009, July 16). Why Tax Information Exchange Agreements are "Toothless". [Online]. Available http://www.cpa2biz.com/Content/media/PRODUCER_CONTENT/New sletters/Articles_2009/Tax/Toothless.jsp . [June 17, 2013].

[31] L.-M. Batrancea, R.-A. Nichita, I. Batrancea and P. Radu, "Multifacets of Tax Evasion in Theory, Surveys, Case Studies, and Economic Experiments," in Advances in Finance and Accounting. Proceedings of the $1^{\text {st }}$ WSEAS International Conference on Finance, Accounting and Auditing (FAA '12), Zlín, Czech Republic, 2012, pp. 378-383.

[32] M. A. Dizdarevic, "The FATCA provisions of the hire act: boldly going where no witholding has gone before," Fordham Law Review, vol. 79, pp. 2967-2994, May 2011.

[33] M. Helminen, EU Tax Law. Direct Taxation, 1st ed., Amsterdam: IBFD, 2009. pp. 279-291.

[34] M. J. McIntyre, "Identifying the New International Standard for Effective Information Exchange," in Tax Treaties: Building Bridges between Law and Economics, M. Lang, P. Pistone, J. Schuch, C. Staringer, A. Storck and M. Zagler, Eds. Amsterdam: IBFD, 2010, pp. 481-516.

[35] M. Keen and J. E. Ligthart, "Information Sharing and International Taxation: A Primer," International Tax and Public Finance, vol.13, pp. 81-110, January 2006.

[36] M. Lang, Introduction to the Law of Double Taxation Conventions, 1st ed., Wien: Linde, 2010. pp. 23-26.

[37] M. Meinzer (2013, January 29), "Towards multilateral automatic information exchange. Current practice of AIE in selected countries," Tax justice network. [Online]. Available: http://www.taxjustice.net/cms/upload/pdf/AIE2012-TJN-Briefing.pdf. [May 05, 2013].

[38] M. Meinzer, M. Hearson, S. Picciotto, N. Shaxson and D. Spencer (2009, June 03), "TAX JUSTICE BRIEFING. Tax Information Exchange Arrangements," Tax justice network. [Online]. Available: http://www.taxjustice.net/cms/upload/pdf/Tax_Information_Exchange_ Arrangements.pdf. [July 4, 2013].

[39] M. P. Devereux, R. Griffith and A. Klemm, "Corporate income tax reforms and international tax competition," Economic Policy, vol. 17, pp. 449-495, October 2002.

[40] M. Salthmarsh (2009, March). "Tax Havens Likely to Be Target of G-20 Nations.", The New York Times. [Online]. Available: http://www.nytimes.com/2009/03/13/business/worldbusiness/13liechten stein.html?_r=0. [June 17, 2013].

[41] M. Vyškovská, Výklad smluv o zamezeni dvojího zdanění ve světle judikatury Nejvyššiho správního soudu a Conseil d'Etat (Francie), 1st ed., Praha: Wolters Kluwer, 2010. [Interpretation of Conventions for Avoidance of Double Taxation in case law of the Supreme Administrative Court and Conseil d'Etat (France)- a book in Czech].

[42] M. Wenz, A. Linn, B. Brielmaier and M. Langer, "Tax Treaty Application: Cross-Border Administrative Issues (Including Exchange of Information, Collection of Taxes, Dispute Settlement and Legal Certainty in Tax Treaty Application," in Tax Treaties: Building Bridges between Law and Economics, M. Lang, P. Pistone, J. Schuch, C. Staringer, A. Storck and M. Zagler, Eds. Amsterdam: IBFD, 2010, pp. 547-578.

[43] OECD (1998). Harmful Tax Competition. An Emerging Global Issue. [Online]. Available: http://www.oecd.org/tax/harmfultaxpractices/1904184.pdf. [December 20, 2012].

[44] OECD (2011), The Multilateral Convention on Mutual Administrative Assisstance in Tax Matters: Amended by the 2010 Protocol, OECD [Online] Publishing.
Available: http://dx.doi.org/10.1787/9789264115606-en. [June 15, 2013]

[45] OECD (2012), "Article 26. Exchange of Information", in Model Tax Covention on Income and on Capital 2010: Full Version, OECD Publishing. Available: http://dx.doi.org/10.1787/9789264175181-29-en. [August 29, 2012].

[46] OECD (2012), "Commentary on Article 26. Concerning the exchange of information", in Model Tax Covention on Income and on Capital 2010. Full Version, OECD Publishing. Available: http://dx.doi.org/10.1787/9789264175181-60-en. [August 29, 2012].
[47] OECD (2012). Automatic Exchange of Information. WHAT IT IS, HOW IT WORKS, BENEFITS, WHAT REMAINS TO BE DONE. Available: http://www.oecd.org/ctp/exchange-of-tax-

information/automaticexchangeofinformationreport.htm. [June 17, 2013].

[48] OECD (2012). Global Forum on Transparency and Exchange of Information for Tax Purposes. Tax Transparency 2012. Report on Progress. [Online]. Available: http://www.oecd.org/tax/transparency/Tax\%20Transparency\%202012_J M\%20MB\%20corrections\%20final.pdf [August 25, 2013].

[49] OECD (2012). Keeping It Sage. THE OECD GUIDE ON THE PROTECTION OF CONFIDENTIALITY OF INFORMATION EXCHANGED FOR TAX PURPOSES. [Online]. Available: http://www.oecd.org/ctp/exchange-of-taxinformation/Keeping\%20it\%20Safe_EN_FINAL_forweb.pdf. [June 13, 2013].

[50] OECD (2012). Update to Article 26 of the OECD Model Tax Convention and its Commentary. Approved by the OECD Council on 17 July 2012. [Online]. Available: http://www.oecd.org/ctp/exchange-of-taxinformation/120718_Article\%2026-ENG_no\%20cover\%20(2).pdf October 23, 2012].

[51] OECD (2013). The Global Forum on Transparency and Exchange of Information for Tax Purposes.Information Brief. July 2013 [Online]. Available:

http://www.oecd.org/tax/transparency/GF\%20Brief\%20Background\%20 presseoifinal_2.pdf [August 27, 2013]

[52] OECD (2013, July 31). Global Forum on Tax Transparency: New reports review jurisdiction's information exchange. [Online]. Available: http://www.oecd.org/tax/globalforumontaxtransparencynewreportsrevie wjurisdictionsinformationexchange.htm [August 28, 2013].

[53] Přehled platných smluv České republiky o zamezení dvojímu zdanění v oboru daní $\mathrm{z}$ př́ijmu, resp. $\mathrm{z}$ príjmu a $\mathrm{z}$ majetku. Č.j.: MF25 190/2013/15-1503. in Finanční zpravodaj 3/2013 Ministerstva financí ČR, vol. XLVII, pp. 68-69, No. 2, 2013. [A List of Valid Conventions for Avoidance of Double Taxation in the Area of Income Taxes; eventually in the Area of Income and Property Taxes - a list published in a bulletin of the Ministry of Finance of the Czech Republic - in Czech language].

[54] T. Rixen and P. Schwarz, "How effective is the European Union's Savings Tax Directive? Evidence from Four EU Member States," Journal of Common Market Studies, vol. 50, pp. 151-168, January 2012.

[55] Tax Justice Network (2011). The Death of International Exchange Agreements? [Online]. Available: http://taxjustice.blogspot.cz/2011/04/death-of-informationexchange.html. [May 22, 2013].

[56] Tax Justice Network (2013). On Exchange of Information for Tax Purposes. [Online]. Available http://www.taxjustice.net/cms/front_content.php?idcat=140 [August 25, 2013].

[57] V. Solilová, "Mezinárodní spolupráce: výměna informací pro daňové účely ve světle nových skutečností - I. část," Daně a právo v praxi, vol. XVII, pp. 32-38, No. 12, 2012. ["International Cooperation: Exchange of Information for Tax Purposes in the Light of New Facts - part I - an article in Czech]

[58] V. Solilová, "Mezinárodní spolupráce: výměna informací pro daňové účely ve světle nových skutečností - II. část," Daně a právo v praxi, vol. XVII, pp. 22-26, No. 3, 2013. ["International Cooperation: Exchange of Information for Tax Purposes in the Light of New Facts - part II - an article in Czech]

[59] V. Tanzi, (1996). Globalization, Tax Competition and the Future of Tax Systems. International Monetary Fund Working Paper No. 96/141 [Online]. Available: http://papers.ssrn.com/sol3/papers.cfm?abstract_id=883038. [December 20, 2012]

[60] V. Tanzi, (2001, March), "Globalization and the Work of Fiscal Termites." Finace \& Development. A quarterly magazine of the IMF. [On-line]. vol. 38, No. 1 Available: http://www.imf.org/external/pubs/ft/fandd/2001/03/tanzi.htm. [December 10, 2012].

\section{Creative Commons Attribution License 4.0 (Attribution 4.0 International, CC BY 4.0)}

This article is published under the terms of the Creative Commons Attribution License 4.0 https://creativecommons.org/licenses/by/4.0/deed.en_US 